\title{
Paleomagnetism of the Cambro-Ordovician McClure Mountain alkalic complex, Colorado
}

\author{
C.S. Lynnes and R. Van der Voo \\ Department of Geological Sciences, University of Michigan, Ann Arbor, MI 48109 (U.S.A.)
}

Received May 17, 1984

Revised version received August 18, 1984

\begin{abstract}
The Middle to Late Cambrian loop in the North American apparent polar wander path (APWP) has been variously attributed to tectonic rotations, remagnetizations and primary magnetizations. Although no primary thermal remanent magnetizations or primary detrital remanent magnetizations have as yet been demonstrated, the temporally self-consistent nature of the loop has been used as an argument for primary magnetizations. We have studied $535 \pm 5 \mathrm{Ma}$ nepheline syenites and syenites of the McClure Mountain alkalic complex, as well as $495 \pm 10$ Ma red trachyte dikes which intruded the complex, in an effort to find a primary TRM. Because Zijderveld analysis yielded consistent results for only one trachyte dike, remagnetization great-circle analysis was employed, giving a pole for the trachyte dikes at the tip of the loop $\left(43^{\circ} \mathrm{N}, 114^{\circ} \mathrm{E}\right)$, while the syenites and nepheline synenites gave a pole at the base of the loop $\left(18^{\circ} \mathrm{N}\right.$, $142^{\circ} \mathrm{E}$ ). The magnetic carrier in the trachytes is hematite which apparently formed during a pervasive hydrothermal alteration. K-Ar whole rock dating of the trachytes suggests a Pennsylvanian age for the alteration, and thus a late Paleozoic remagnetization of the trachytes. Thus, the low-latitude Cambrian pole is confirmed, but we find no evidence in this study to support the primary nature of the Cambrian APWP.
\end{abstract}

\section{Introduction}

Since the Wilson cycle was first proposed for peri-Atlantic orogenic belts [1], Paleozoic continental reconstructions have proven to be a major challenge. Significant contributions have come from the field of paleomagnetism through the determination of apparent polar wander paths (APWPs) for different continents. Still, many segments of the APWPs are poorly defined or questionable, even for well-studied continents; one such segment is the Cambrian section of the North American APWP. Published poles define a loop extending from $5^{\circ} \mathrm{N}, 158^{\circ} \mathrm{E}$ (the Lower Cambrian Tapeats formation [2]) northwest to $59^{\circ} \mathrm{N}, 89^{\circ} \mathrm{E}$ (the upper Middle Cambrian Abrigo formation [2]) and returning to $6^{\circ} \mathrm{N}, 159^{\circ} \mathrm{E}$ (the Upper Cambrian Point Peak member of the Wilberns formation [3]). There are two reasons why the loops is suspect: (1) it requires an unusual se- quence of rotations and counterrotations for the North American continent during the Cambrian, and (2) the upper part of the loop overlaps the upper Paleozoic segment of the North American APWP. Thus some of the poles may represent a remagnetization. In support of the validity of the loop, it has been noted [4,5] that a number of poles from Cambrian sedimentary formations fall between these extremes, always in a stratigraphically consistent manner; however, conclusive evidence against remagnetization, such as demonstration of a Cambrian detritral remanent magnetization (DRM) or thermoremanent magnetization (TRM), has not yet been presented. Furthermore, Larson et al. [6] report a pole near the top of the loop for the Black Canyon diabases in southwestern Colorado, which are dated at $497 \pm 16 \mathrm{Ma}$ [6], clearly younger than the Point Peak pole of Van der Voo et al. [3] at the base of the loop and thus discordant with the loop. However, the Black Canyon 
pole has not been conclusively shown to represent a primary TRM and is far removed from the Lower Ordovician poles of Jackson et al. [7] and Dankers and Lapointe [8], which are also near the base of the loop. In addition, French et al. [9] report three populations of site directions (to which they refer as Groups I, II and III) from basic and alkalic dikes in and around the $\mathrm{McClure}$ Mountain complex. The Group I and Group II directions give poles near the lower half of the loop, while the Group III directions give a pole at the top of the loop. Unfortunately, the radiometric dates of the rocks sampled could only constrain their ages between 704 and $485 \mathrm{Ma}$ [10]. The McClure Mountain complex, however, has precise dates for two units, a Middle Cambrian syenite-nepheline syenite pluton and a Cambro-Ordovician set of trachyte dikes: these rocks were sampled in an attempt to obtain a primary TRM in order to evaluate the validity of this problematic APWP loop.

\section{Geology and sampling}

The McClure Mountain complex is located in the Wet Mountain Range, an en echelon extension of the Front Range in south-central Colorado (Fig. 1). The complex was intruded into a lower Proterozoic migmatitic gneiss, as were two similar complexes at Gem Park, $5 \mathrm{~km}$ to the southwest, and Democrat Creek, $7 \mathrm{~km}$ to the southeast $[11,12]$. The McClure Mountain complex is the largest of the three, covering about $80 \mathrm{~km}^{2}$. It is compositionally bimodal, consisting of a small gabbroic complex in the northeast and a younger alkalic complex. The latter comprises, in order of intrusion: (1) ijolite, heavily brecciated by later intrusions, (2) syenite, (3) nepheline syenite and (4) assorted lamprophyre and brick-red trachyte dikes [13]. The nepheline syenite and syenite have recently been dated at $535 \pm 5 \mathrm{Ma}$ (14-point mineral-whole rock $\mathrm{Rb}-\mathrm{Sr}$ isochron [14]). These rocks also yielded average hornblende and biotite $\mathrm{K}$-Ar dates of $520 \mathrm{Ma}$ and $508 \mathrm{Ma}$, respectively. Sphene and apatite fission-track dates are $506 \pm 43$ $\mathrm{Ma}$ and $293 \pm 62 \mathrm{Ma}$, respectively [15]. The red trachyte dikes from the McClure Mountain and
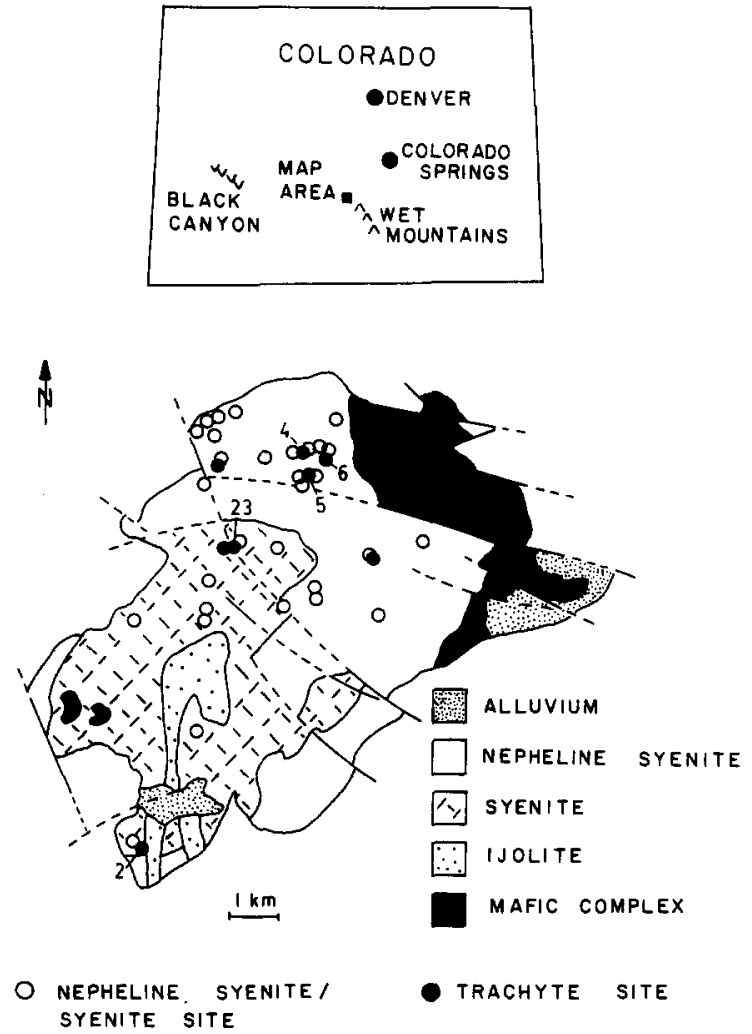

Fig. 1. Geologic map of the McClure Mountain complex with sampling localities [12]. Trachyte sites MCM 2, MCM 4, MCM 5, MCM 6 and MCM 23 are identified.

Gem Park complexes have been dated at $495 \pm 10$ Ma (4-point whole rock $\mathrm{Rb}$-Sr isochron [15]) (Table 1).

Thirty-one samples from eight trachyte dike sites, 36 samples from eight nepheline syenite sites, and 130 samples from 22 syenite sites were collected. Almost all were hand samples oriented with a solar compass when possible or a Brunton when necessary. A comparison of the two confirmed that local magnetic effects did not introduce a significant orientation error. The contact between a $3 \mathrm{~m}$ wide trachyte dike and the syenite pluton was exposed at one site and a contact test was attempted but proved to be inconclusive.

The trachytes are aphanitic to finely phaneritic, often containing euhedral feldspar phenocrysts up to $3 \mathrm{~mm}$ in length; the syenites exhibit mediumgrained to pegmatitic textures and range from 
TABLE 1

Radiometric dates for the McClure Mountain complex

\begin{tabular}{lllr}
\hline Rock type & Analysis & Date (Ma) & Reference \\
\hline Syenite/nepheline syenite & Rb-Sr; 4 pt. whole rock & $704 \pm 70$ & {$[9]$} \\
Syenite/nepheline syenite & Rb-Sr; 5 pt. whole rock & $517 \pm 14$ & {$[9]$} \\
Syenite/nepheline syenite & Rb-Sr; 14 pt. mineral-whole rock & $535 \pm 5$ & {$[13]$} \\
Syenite/nepheline syenite & Rb-Sr; 8 pt. mineral-whole rock & $521 \pm 10$ & {$[14]$} \\
Syenite/nepheline syenite & K-Ar; averaged hornblende date & 520 & {$[14]$} \\
Syenite & K-Ar; averaged biotite date & 508 & {$[14]$} \\
Trachyte dikes & fission-track; sphene & $506 \pm 43$ & {$[14]$} \\
Syenite & Rb-Sr; 4 pt. whole rock & $295 \pm 10$ & {$[14]$} \\
\end{tabular}

white to flesh-colored, while the nepheline syenites have similar textures but are generally more gray in appearance.

\section{Paleomagnetic results}

The natural remanent magnetization (NRM) directions for both the trachyte dikes and the plutonic rocks are largely confined to the lower hemisphere but show a great deal of scatter (Fig. 2). The trachyte NRMs streak southeasterly from the present-day field direction and the plutonic NRMs in an easterly direction, suggesting that the rocks might retain some ancient direction. The rocks were subjected to thermal and alternating

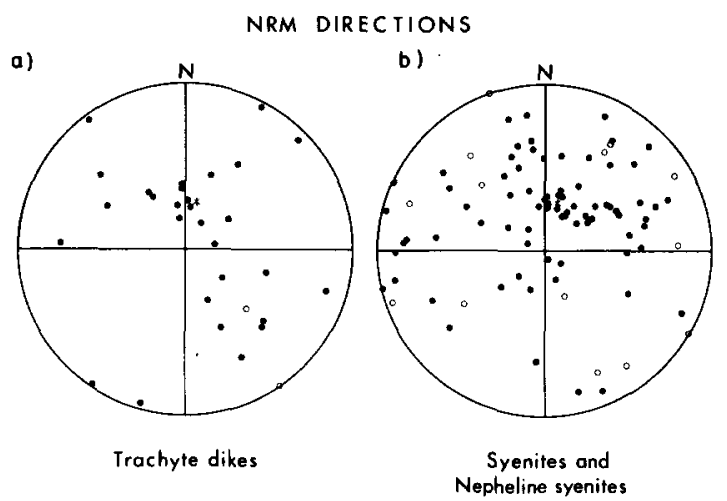

Fig. 2. Equal area projection of NRM sample directions for (a) trachytes and (b) nepheline syenites and syenites. Open circles indicate upper hemisphere projections, solid circles indicate lower hemisphere projections. Asterisks indicate the present-day field direction. field demagnetization and vector analysis [16] in an attempt to isolate that direction. The syenites and nepheline syenites ranged from $10^{-1}$ to $10^{-4}$ $\mathrm{A} / \mathrm{m}$ and the trachytes from $10^{-3}$ to $10^{-5} \mathrm{~A} / \mathrm{m}$ in NRM intensity before demagnetization. Most specimens were demagnetized until $99 \%$ of the magnetization was removed.

\subsection{Trachyte dikes}

Thermal demagnetization of the trachytes often produced univectorial decays on Zijderveld plots after removal of a low-temperature component. Except for one dike (Fig. 3a), however, the directions indicated by such univectorial decays were inconsistent within sites (Fig. 3b). Only the four samples from site MCM 5 gave consistent directions using Zijderveld analysis. Although alternating field (AF) treatments up to $100 \mathrm{mT}$ failed to clean these samples to a point where a linear decay

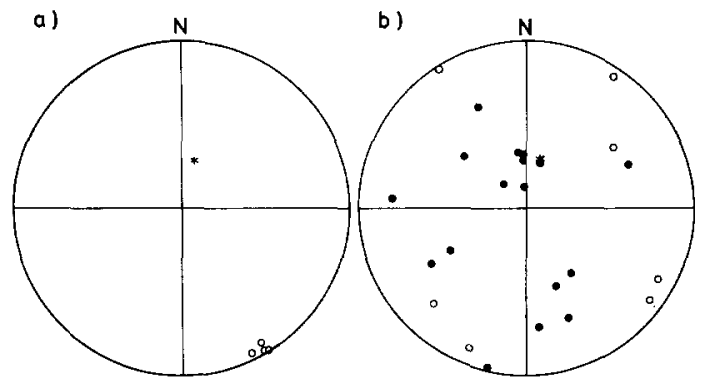

Fig. 3. Equal area projections of trachyte sample directions from Zijderveld analysis [15] for (a) site MCM 5 and (b) all others. Symbols as in Fig. 2. 
to the origin could be discerned, subsequent thermal demagnetization resulted in a linear decay to the origin after $150-300^{\circ} \mathrm{C}$.

Alternating field treatments failed to isolate consistent directions in samples from other trachyte sites. The decay paths of some samples are arcuate, implying overlapping coercivity spectra for two or more components; other decay paths proceed in a straight line to a point displaced from the origin (Fig. 4a), indicating a remaining component and resulting in widely scattered directions. In both cases, remagnetization great-circle analysis [17] can sometimes identify a common direction among the specimens. The directions of the two highest coercivity components in a specimen define a plane which must contain any linear combination of those two vectors. Thus, no matter how the decay proceeds during demagnetization, the resultant vector (the direction measured after each step) will always lie in that plane (Fig. 4b). If a number of specimens carry a common direction, their greatcircle demagnetization paths will intersect at the point representing that direction. This allows the determination of a mean characteristic direction even if that direction cannot be isolated in individual demagnetizations. a)

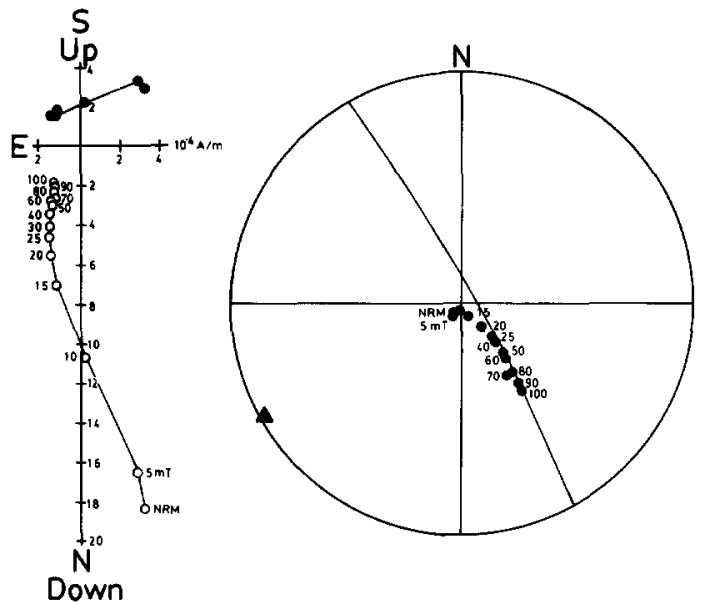

Fig. 4. AF demagnetization of a representative trachyte dike sample (site MCM 23) shown on (a) Zijderveld projection and (b) equal area projection. Open circles in (a) indicate vertical projection, closed circles indicate horizontal projection. Symbols in (b) are as in Fig. 2. The triangle is the pole to the great circle.
The paths for all thermal and AF demagnetizations were plotted on equal area projections, and great circles were fitted for well-defined paths using a least squares method [17]. This method yielded well-constrained great-circle intersections for three trachyte sites (MCM 5, 4 and 23; Fig. $5 \mathrm{a}-\mathrm{c}$ ). (The other trachyte sites yielded only one or two great circles.) The great-circle intersection for site MCM 5 is in excellent agreement with the directions from Zijderveld analysis, giving a southeasterly, nearly horizontal direction (Figs. 3a and 5a). The mean direction from great-circle analysis for site MCM 23 is more southerly and that for site MCM 4 more easterly, but the overall agreement with the stable endpoint directions of site MCM 5 is still good. Poles to all sample great circles obtained from trachyte demagnetizations define a great circle, the pole of which represents the mean intersection of the great circles and hence the common direction among the trachytes.
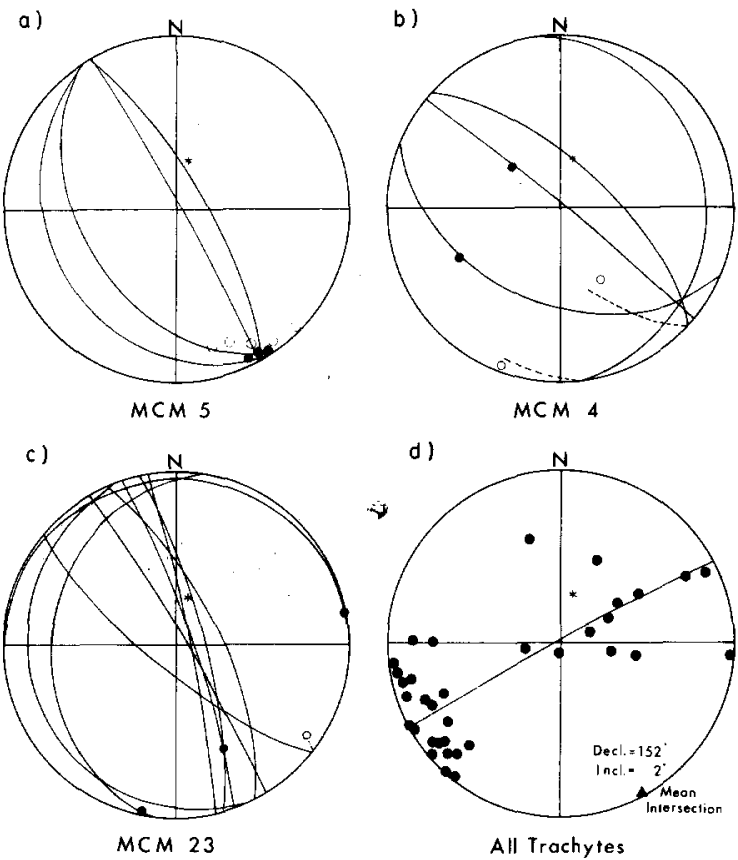

Fig. 5. Remagnetization great circles and specimen directions from Zijderveld analysis are shown in (a) to (c) for three trachyte sites. The poles to the great circles from all trachyte sites are shown in (d); the pole to the great circle through these points, shown as a triangle, gives the mean trachyte direction. All great circles and great-circle poles are plotted on lower hemisphere equal area projections. 
As with the individual sites, the direction is southsoutheasterly and nearly horizontal. This corresponds to a paleomagnetic pole at $43^{\circ} \mathrm{N}, 114^{\circ} \mathrm{E}$, which is near the northwestern tip of the Cambrian APWP loop.

\subsection{Syenites and nepheline syenites}

The syenites and nepheline syenites also give inconclusive results from Zijderveld analysis. Thermal demagnetization produced inconsistent directions, and AF treatment up to $100 \mathrm{mT}$ was insufficient to isolate the high coercivity component. Great-circle analysis was once more attempted with some success using AF demagnetizations. (Thermal demagnetizations rarely defined great circles, either because the components had similar blocking temperature spectra or because thermal demagnetization introduced too much noise.) Alternating field demagnetization paths spanning arcs less than $20^{\circ}$ were considered to be imprecise and were excluded from the analysis. The poles to the great circles were then contoured (Fig. 6a); these comprise three populations we have designated A, B and C. (Population A includes two subpopulations which we have designated A1 and A2.) The majority of the great circles (represented by the poles in population A) intersect in a northerly and steeply down direction, corresponding to the present-day field or geocentric dipole direction. Any great circle that gives a pole in population A represents two components, a recent one and some other component. Were this latter component randomly distributed (e.g., as with that induced by lightning strikes or a laboratory viscous component), the great-circle poles would be evenly distributed along the great circle corresponding to the recent direction. Thus the high density of poles in subpopulation A1 suggests that the second component is non-random and therefore representative of an ancient component. Furthermore, populations B and C indicate the presence in some samples of two components exclusive of a recent one, implying either two ancient components or an ancient component and a viscous remanent magnetization. A great circle can be drawn through populations $\mathrm{Al}$, $B$ and $C$, further supporting the presence of an ancient component in the syenites and nepheline syenites. The direction given by this great circle is east-southeasterly and shallow; this is strikingly similar to the Group I directions found by French et al. [9]. The virtual geomagnetic pole given by this direction lies at $18^{\circ} \mathrm{N}, 142^{\circ} \mathrm{E}$, near the base of the Cambrian APWP loop.

In order to compare the paleomagnetic results from this study with those from the lamprophyre and alkalic dikes studied by French et al. [9], great circles were constructed such that they contain each of the site means from the latter study and
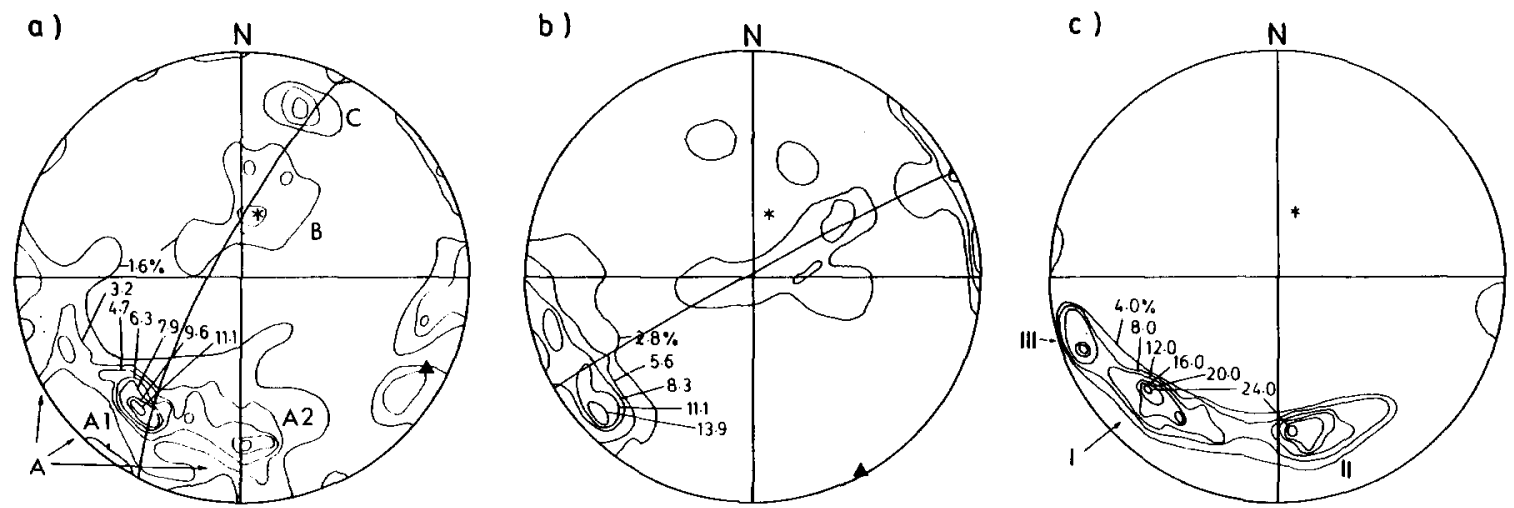

Fig. 6. Density contour plots of remagnetization great-circle poles are plotted on lower hemisphere equal area projections for (a) syenites and nepheline syenites $(N=63)$, (b) trachytes $(N=36)$ and (c) basic and alkalic dikes studied by French et al. [9] $(N=25)$. In (a) and (b) the poles to the great circles shown define mean common directions (triangles) for all samples of the rock type. The poles in (c) were synthesized by inverting site directions around the geocentric dipole direction. 
the geocentric dipole direction. When the poles to these great circles (Fig. 6c) are plotted next to the great-circle poles for the trachytes (Fig. $6 \mathrm{~b}$ ) and the plutonic rocks (Fig. 6a), it is apparent that each of the three groups of directions found by French et al. is matched by a population or subpopulation of great-circle poles in this study. Specifically, the Group III great-circle poles of French et al. correspond to the trachyte great-circle poles (Fig. 6b); the Group I great-circle poles correspond to subpopulation $\mathrm{Al}$ of the plutonic great-circle poles; and the Group II great-circle poles correspond to the subpopulation $\mathrm{A} 2$ of the plutonic great-circle poles

a)

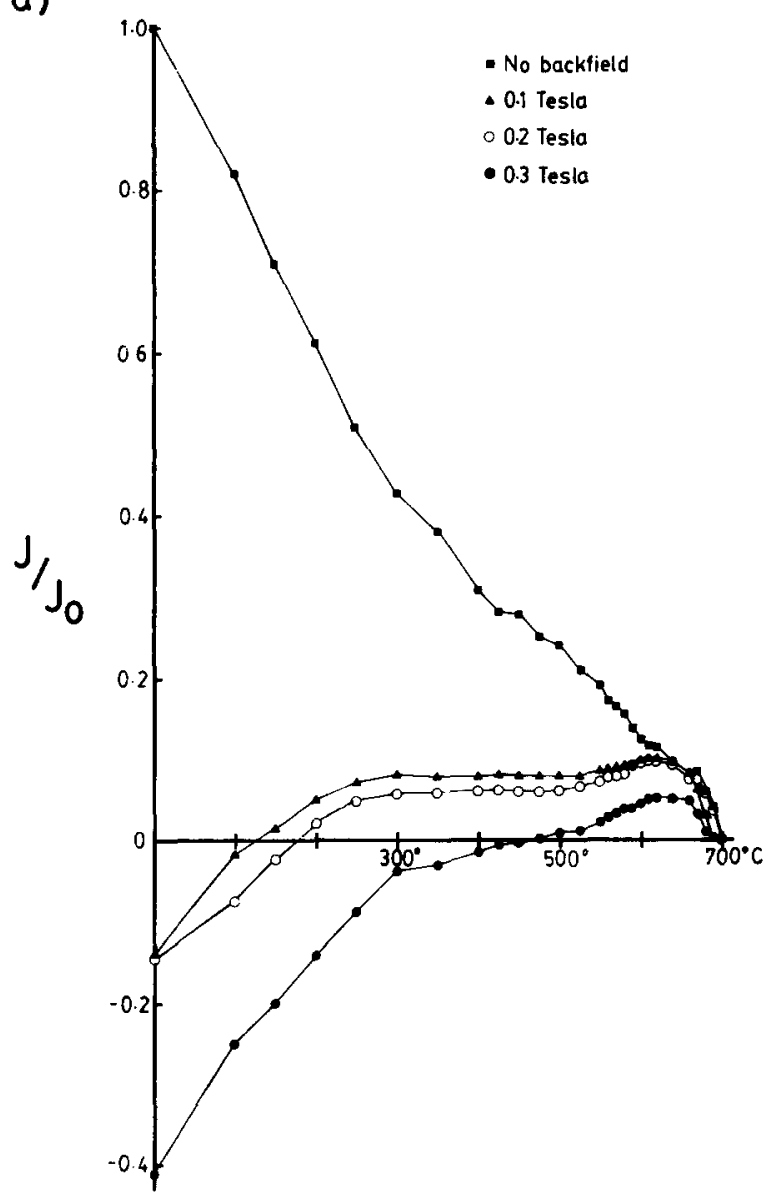

\subsection{Magnetic carriers}

The presence of high blocking temperatures in the trachytes of this study indicates the carrier in these rocks to be hematite, suggesting a chemical remagnetization. In thin section, the hematite appears both as small discrete grains and as a fine, nearly indistinguishable dust pervading all silicate minerals save the centers of some quartz phenocrysts. Isothermal remanent magnetization (IRM) experiments also indicated the presence of a lowcoercivity component in the trachytes. In an effort to determine whether this component could be carried by magnetite, a possibly primary magnetic

b)

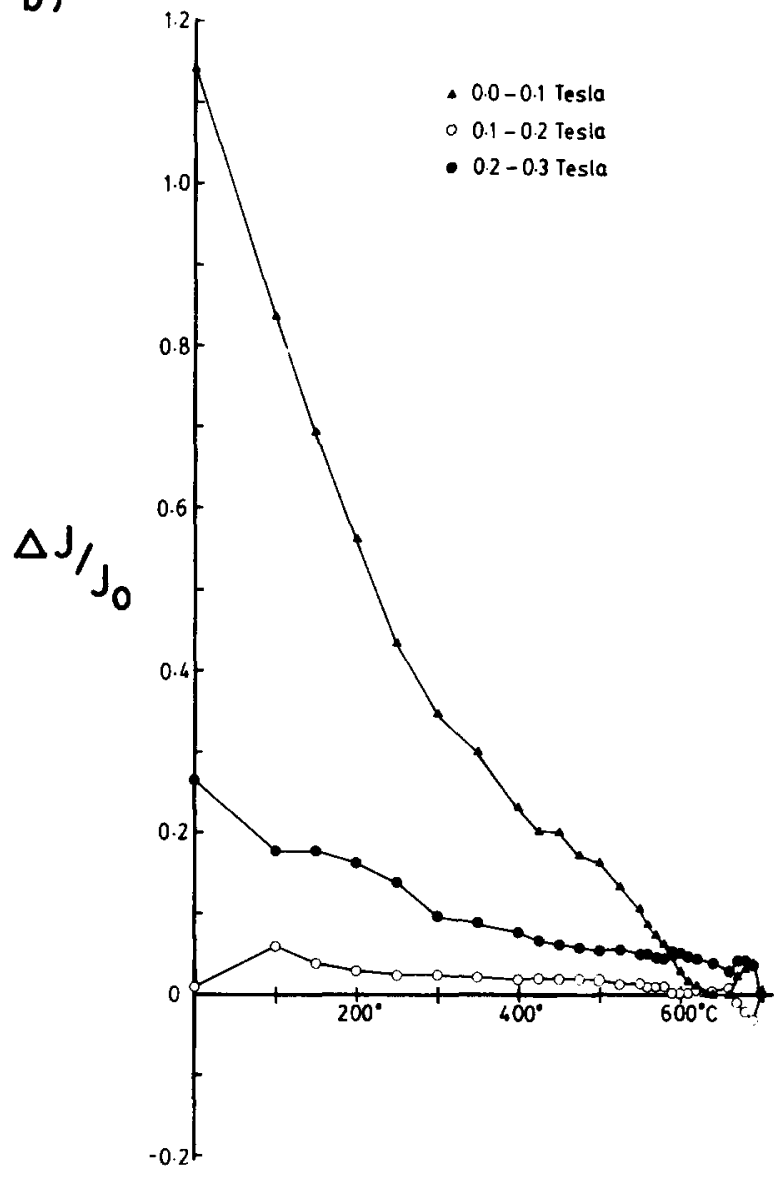

Fig. 7. Thermal demagnetizations of IRM plotted for (a) various backfields and (b) different coercivity ranges. The latter plot was obtained by subtracting successive curves in (a). 
carrier, we applied a field of $0.9 \mathrm{~T}$ along the core axis to four specimens of the same sample from site MCM 5 and then applied a backfield of $0.1 \mathrm{~T}$ to one specimen, $0.2 \mathrm{~T}$ to another, and $0.3 \mathrm{~T}$ (the theoretically highest saturation point for magnetite [18]) to a third specimen. All four specimens were then thermally demagnetized. The vertical component for each specimen was then normalized to its value before the backfield treatment and plotted against temperature (Fig. 7a). By subtracting each curve from the one for the next higher backfield treatment, we were then able to isolate the thermal behavior of the separate coercivity ranges $0-0.1$, $0.1-0.2$ and $0.2-0.3 \mathrm{~T}$ (Fig. 7b). It is immediately apparent from these data that the bulk of the IRM has a low coercivity and blocking temperature. However, the important feature of these measurements is the behavior of the specimens near $578^{\circ} \mathrm{C}$, the Curie point of magnetite. In Fig. 7a, the intensity of the backfield specimens continues to increase past $600^{\circ} \mathrm{C}$, indicating hematite, but each of these curves includes magnetization from high-coercivity material. There is a break in slope at about $580^{\circ} \mathrm{C}$ in the curve for specimens to which no backfield was applied, which might indicate magnetite; however, this break is no more obvious than the breaks in slope between $400^{\circ}$ and $500^{\circ}$. In Fig. $7 \mathrm{~b}$, both the $0-0.1$ and $0.2-0.3 \mathrm{~T}$ components have significant magnetizations which remain well past the Curie point, indicating the presence of low-coercivity hematite. Therefore, we are unable to show the low-coercivity component to be carried by magnetite. Thus, although magnetite may exist in the trachytes, there is no compelling evidence for significant quantities of remanence-carrying magnetite.

Magnetization in the plutonic syenites and nepheline syenites, on the other hand, appears to be carried by magnetite or Ti-magnetite. The magnetization is almost always removed by $590^{\circ} \mathrm{C}$, and the syenite saturated by $0.3 \mathrm{~T}$ in IRM experiments. Furthermore, no hematite is observed in thin sections of these plutonic rocks.

\section{Discussion}

Both the nepheline syenite/syenite paleomagnetic pole and the trachyte pole could be Cam- brian since both fall on or near the Cambrian loop (Fig. 8a). However, the trachyte pole also falls near the upper Paleozoic segment of the North American APWP (Fig. 8b), thus introducing the same age ambiguity that has plagued other poles from Cambrian rocks that fall on this section of the loop $[19,2,9]$. The early Ordovician Rb-Sr date for the trachytes [15] suggests that they postdate the Upper Cambrian Llano Uplift formations and specifically the Wilberns formation, which has been dated at $507 \pm 12 \mathrm{Ma}$ using the Rb-Sr method on glauconite [20]. However, this in itself is not compelling evidence for an upper Paleozoic remagnetization of the McClure Mountain trachytes: firstly, the trachyte date is somewhat unreliable as it is based on only a four-point isochron (one of which was obtained from a sample from the Gem Park complex); secondly, the magnetic carrier of the Llano Uplift magnetizations is hematite and could therefore be carrying early diagenetic magnetizations (which could preserve the stratigraphic progression of the poles) rather than primary magnetizations.

Since both deuteric and later hydrothermal fluids could have formed the hematite in the trachytes, the age of the magnetization cannot be constrained solely on a mineralogical basis. However, since the hematite also appears to be associated with sericitization of the feldspars, it should be possible to date this alteration and, by inference, the magnetization. Therefore whole rock samples from five different trachyte dikes were dated using the K-Ar method (Table 2). Although these dates have a wide spread, from 440 to 300 $\mathrm{Ma}$, none are close enough to the early Ordovician date [15] to suggest that the alteration was deuteric. Furthermore, although it is relatively easy in this case to explain dates which are "too old" by calling on an incomplete mobilization of ${ }^{40} \mathrm{Ar}$, it is considerably more difficult to explain dates which are "too young" without invoking the very alteration whose age we are seeking. It is also noteworthy that the site which gave by far the most consistent paleomagnetic results (MCM 5) also gave a commensurately younger date than the other sites; this relationship is consistent with the hypothesis that the pervasiveness of the alteration controlled both the diffusion of ${ }^{40} \mathrm{Ar}$ and the for- 

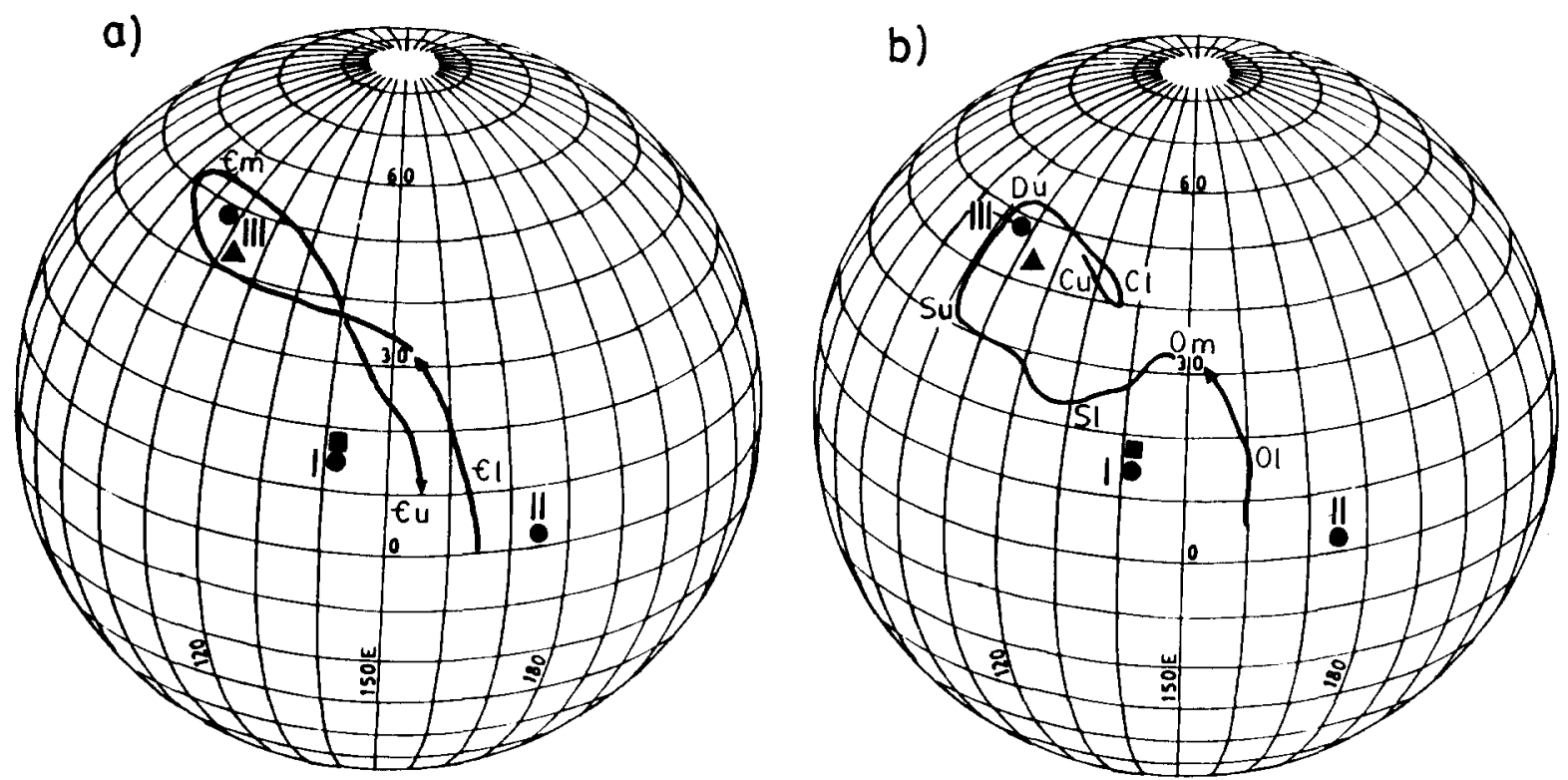

Fig. 8. Poles from this study superimposed on the North American apparent polar wander path for the (a) Cambrian and (b) Ordovician through Carboniferous periods (after Watts et al. [4]). Triangle is the trachyte pole, square is the nepheline syenite/syenite pole. Poles I, II and III represent poles from the Group I, II and III directions, respectively, of French et al. [9].

mation of hematite. If we assume that the alteration was roughly synchronous for all the dikes, then the youngest age date is most probably close to the actual age of alteration. This date $(300 \pm 11$ Ma) also coincides with the apatite fission-track date of $293 \pm 62 \mathrm{Ma}$ which Olson et al. [15] attributed to regional uplift. Indeed, this date corresponds to a period of extensive Pennsylvanian block faulting [21], which appears to be related to hydrothermal fluid migration elsewhere in Colorado [22]. Thus, the magnetization of the trachytes seems to be inescapably upper Paleozoic, and probably Pennsylvanian. The validity of the Cambrian APWP loop is thus not supported by

TABLE 2

$\mathrm{K}$-Ar whole rock dates for trachyte dikes

\begin{tabular}{ll}
\hline Site & Date (Ma) \\
\hline MCM 5 & $300 \pm 11$ \\
MCM 4 & $403 \pm 14$ \\
MCM 2 & $425 \pm 15$ \\
MCM 23 & $435 \pm 15$ \\
MCM 6 & $440 \pm 15$ \\
\hline
\end{tabular}

the trachyte pole despite the coincidence of the pole and the tip of the Cambrian loop.

The magnetization of the syenites and nepheline syenites appears to be carried by magnetite or Ti-magnetite; these rocks also exhibit no features of the alteration which is so pervasive in the trachyte dikes which intrude them. Thus, chemical remagnetization of the syenites and nepheline syenites can be largely discounted. The biotite $\mathrm{K}-\mathrm{Ar}$ date of $508 \mathrm{Ma}$ and the sphene fission-track date of $506 \pm 43 \mathrm{Ma}$ [15] imply temperatures less than about $250^{\circ} \mathrm{C}$ since the end of the Cambrian, making a complete thermal remagnetization unlikely; however, given the length of time between these dates and the apatite fission track date of $293 \pm 62 \mathrm{Ma}$ [15], a partial thermal remagnetization cannot be discounted. Unfortunately, great-circle analysis was only possible on the AF demagnetized specimens in this study; thus the great-circle directions could not be correlated with blocking temperatures. However, the correspondence of the directions from this study with those of French et al. [9] suggests that the age of the poles given by their Group I and II directions can 
now be constrained to be mid-Cambrian or later (the presumed age of the syenites and nepheline syenites). The locations of these poles further constrain their ages: the pole given by the Group II directions falls near the base of the loop, restricting it to either the Lower Cambrian or Upper Cambrian segment of the path, while the pole given by the Group I directions falls near the Upper Cambrian to Lower Ordovician segment of the path.

In conclusion, neither pole from the plutonic rocks falls near the upper Paleozoic APWP for North America, while the trachyte magnetization does conform to the Pennsylvanian section of the path. The carrier in the trachytes appears to be hematite, and the whole rock K-Ar dates suggest that the hematite results from extensive hydrothermal alteration during the Pennsylvanian. Thus, we are unable to confirm the Cambrian APWP polar wander loop in this study.

\section{Acknowledgements}

We thank Bruce H. Wilkinson, Donald P. Elston, and an anonymous reviewer for helpful comments on the manuscript. We also thank Eric J. Essene and John W. Geissman for many worthwhile suggestions, and the latter for help in the field as well. We greatly appreciate Marie I. Schatz's help in the preparation of the manuscript. The K-Ar dates were provided by a Geochron Laboratories Research Grant. This project was supported by a Sigma Xi grant and NSF grant 81-03031.

\section{References}

1 J.T. Wilson, Did the Atlantic close and then reopen?, Nature 221, 676-681, 1966.

2 D.P. Elston and S.L. Bressler, Paleomagnetic poles and polarity zonation from Cambrian and Devonian strata of Arizona, Earth Planet. Sci. Lett. 36, 423-433, 1977.

3 R. Van der Voo, R.B. French and D.W. Williams, Paleomagnetism of the Wilberns Formation (Texas) and the late Cambrian paleomagnetic field for North America, J. Geophys. Res. 81, 5633-5638, 1976.

4 D.R. Watts, R. Van der Voo and S.C. Reeve, Cambrian paleomagnetism of the Llano Uplift, Texas, J. Geophys. Res. 85, 5316-5330, 1980.

5 D.R. Watts, R. Van der Voo and R.B. French, Paleomagnetic investigation of the Cambrian Waynesboro and Rome formations of the Valley and Ridge Province of the Appalachian Mountains, J. Geophys. Res. 85, 5331-5343, 1980.

6 E.E. Larson, P.E. Patterson, G. Curtis, R. Drake and F.E. Mutschler, Petrologic, paleomagnetic, and structural evidence of a Paleozoic rift system in Oklahoma, Colorado, and Utah, Geol. Soc. Am. Bull. (in press).

7 M. Jackson, R. Van der Voo and D.R. Watts, Paleomagnetism of the lower Ordovician Oneota Dolomite, Upper Mississippi River Valley (abstract), EOS 64, 216, 1983.

8 P. Dankers and P. Lapointe, Paleomagnetism of lower Cambrian volcanics and a cross-cutting Cambro Ordovician dyke from Buckingham (Quebec), Can. J. Earth Sci. 18, 1174-1186, 1981.

9 R.B. French, D.H. Alexander and R. Van der Voo, Paleomagnetism of upper Precambrian to lower Paleozoic intrusive rocks from Colorado, Geol. Soc. Am. Bull. 88, 1785-1792, 1977.

10 M.D. Fenton and G. Faure, $\mathrm{Rb}-\mathrm{Sr}$ whole-rock age determinations of the Iron Hill and McClure Mountain carbonatite-alkalic complexes, Colorado, Mountain Geol. 7, 269-275, 1970.

11 R.B. Taylor, G.R. Scott, R.A. Wobus and R.C. Epis, Reconnaissance geologic map of the Royal Gorge quadrangle, Fremont and Custer Counties, Colorado, U.S. Geol. Surv. Misc. Inv. Ser., Map I-869, 1975.

12 R.B. Taylor, G.R. Scott, R.A. Wobus and R.C. Epis, Reconnaissance geologic map of the Cotopaxi 15-minute quadrangle, Fremont and Custer Counties, Colorado, U.S. Geol Surv. Misc. Inv. Ser., Map 1-900, 1975.

13 D.H. Alexander, Geology, mineralogy, and geochemistry of the McClure Mountain alkalic complex, Fremont County, Colorado, 327 pp., Ph.D. Thesis, University of Michigan, 1981 (unpublished).

14 T.J. Armbrustmacher and C.E. Hedge, Genetic implication of minor element and Sr-isotope geochemistry of alkaline rock complexes in the Wet Mountains area, Fremont and Custer counties, Colorado, Contrib. Mineral. Petrol. 79, 424-435, 1982.

15 J.C. Olson, R.F. Marvin, R.L. Parker and H.H. Mehnhert, Age and tectonic setting of lower Paleozoic alkalic and mafic rocks, carbonatites, and thorium veins in south-central Colorado, J. Res. U.S. Geol. Surv. 5, 673-687, 1977.

16 J.D.A. Zijderveld, AC demagnetization of rocks: analysis of results in: Methods in Paleomagnetism, D.W. Collinson, K.M. Creer and S.K. Runcorn, eds., pp. 254-286, Elsevier, Amsterdam, 1967.

17 H.C. Halls, A least-squares method to find remanence direction from converging remagnetization circles, Geophys. J.R. Astron. Soc. 45, 297-304, 1976.

18 M.W. McElhinny, Paleomagnetism and Plate Tectonics, 358 pp., Cambridge University Press, Cambridge, 1973.

19 E.E. Larson and F.E. Mutschler, Anomalous paleomagnetic 
pole from isotopically dated Cambro-Ordovician intrusives in Colorado, Geol. Soc. Am. Bull. 82, 1657-1666, 1969.

20 J.P. Morton and L.E. Long, Rb-Sr ages of Paleozoic glauconites from the Llano region of central Texas (abstract), Geol. Soc. Am. Abstr. Prog. 10, 22-23, 1978.

21 R.H. De Voto, Pennsylvanian stratigraphy and history of
Colorado in: Colorado Geology, Rocky Mountain Assoc. Geol., 1980 Symposium, pp. 71-102, 1980.

22 R.A. Horton, J.W. Geissman and R.H. De Voto, Late Paleozoic dolomitization of Leadville limestone (Central Colorado) and implications for genesis of $\mathrm{Pb}-\mathrm{Zn}-\mathrm{Ag}$ deposits, Geol. Soc. Am. Abstr. Prog. 15, 599, 1983. 